\title{
Validation of Performance Assessment Instrument on Lay-Up
}

\author{
Muhammad Irvan Eva Salafi ${ }^{1, *}$ Wawan Sundawan Suherman ${ }^{1}$, Bernadeta Suhartini ${ }^{1}$ \\ ${ }^{1}$ Faculty of Sport Sciences, Universitas Negeri Yogyakarta, Yogyakarta, Indonesia \\ "Corresponding author.Email: irvan.salafi@uny.ac.id
}

\begin{abstract}
The purpose of this research was to assess the content validity of the Lay-up performance assessment. This is critical due to its ability to review objectively and its application as material for coach and physical education teacher evaluation. Furthermore, the method used was research evaluation with documents as the subject, and ten coaches are involved as experts, and the test validation is dependent on their integrity. The discussion is based on data gathered from the research instrument, precisely the judgment sheet. The Content Validity Ratio (CVR) formula, obtained the value of the ratio between 0.80 to 1.00 developed by Lawshe, was used in the analysis. The results showed that the values obtained were more significant than 0.05 , with indicators of 3 phases (prepare, implementation, and followthrough). As a result, it can be concluded that the performance assessment instrument on lay-up was observed to have high-value validity contents.
\end{abstract}

Keywords: content validity, performance assessment, lay-up.

\section{INTRODUCTION}

Basketball is one of the world's most popular and extensively watched sports. Today, the sport of basketball is proliferating. This can be proven by the establishment of more clubs or activities in the school environment and the many basketball championships that are regional, national, and international. Basketball began as a non-contact sport, but it has evolved into a physically demanding sport in anticipated contact [1].

Basketball is not simply a team sport, but it also necessitates individual abilities, including shooting, passing, and dribbling. The most critical element of the fundamental basketball techniques is shooting. Shooting is one of the most critical aspects of the game, and it takes a lot of practice and strong, scientifically-based models [2]. Point is scored when the ball is thrown (shot) into a hoop of 18 inches in diameter. The game is won by the team that has the most points.

The lay-up is one of the most fundamental shots in basketball. The lay-up shot is used near the basket after a cut or drive [3], and getting close to the basket's rim and evading more prominent defenders' blocks is the key challenge when making a lay-up [4]. Lay-up success still necessitates the use of the proper methods and processes to maximize the shot's results. Proper board usage will boost the odds of a successful attempt when a player approaches the basketball hoop from the right or left side [5][6].

Players shoot with various techniques, which are influenced by a variety of parameters such as distance, angle, and player type [7]. The speed of the prefix in stepping, the angle at which the knee is bent, the strength of the hands and feet, the angle at which the ball is released, the view, and the technique for configuring the body position at the time of lay up all play a role in lay up success.

For a valid and reliable assessment of performance, the assessor must be knowledgeable about the performance indicators [8]. When used correctly, a rubric can assist in maintaining a process-oriented approach to education. Students learn to increase their learning abilities by achieving specific standards by transferring their learning products up the rubric scale. 
A rubric is an essential tool for ensuring the validity, reliability, and transparency of performance evaluations [9].

The reality is that on the field, there are still athletes or students who have not been able to practice the correct lay-up techniques so that the ball does not go into the basket or turn over. Although other variables affect the effectiveness of lay-ups, the proper application of the method cannot be overlooked as a determining factor of the ball into the ring. In assessing lay-up techniques that employ references that may be verified for quality, the performance test must be performed on it. It is believed that the correct performance in lay-up shoot approaches will be determined by using the performance test. So that it can be used as one of the reference materials for assessment and evaluation of shooting techniques, particularly layup shots, and that it can be used as one of the reference materials for the assessment of shooting techniques.

\section{METHOD}

There were ten practitioners involved in this study as respondents. The participants were all basketball coaches with a high level of competence. This research instrument is a judgement sheet of the instructions for the lay-up performance assessment. Experts determine if an item is "essential" or "not essential" for implementing the test criteria. Before the test, experts are allowed to review the test guidelines. Lawshe's Content Validity Ratio was employed as a statistical data analysis technique in this study [10][11][12]. The formula is as follows.

$\mathrm{CVR}=\frac{(n e-(N: 2))}{N: 2}$

\section{Description:}

CVR : Content Validity Ratio

$\mathrm{Ne}$ : The number of judges that responded "essential."

$\mathrm{N} \quad$ : Total number of judges.

\section{Research Procedure}

Ten lay-up shots are required of athletes, each with a rubric reference for the value of implementation. Correct indicators in lay-up and rubric shooting techniques have been created based on the source of literature studies and on-court observations. Ten experts have validated them in the sport of basketball. Rubric test performance as described below:
Table 1. Rubric indicators of lay up shooting technique

\begin{tabular}{|c|c|}
\hline Phase & Indicator \\
\hline Preparatory & $\begin{array}{l}\text { - Catch the ball with ease } \\
\text { - Viewing the basketball } \\
\text { hoops with an acute } \\
\text { concentration } \\
\text { - Step with the balance body } \\
\text { position }\end{array}$ \\
\hline Implementation & $\begin{array}{l}\text { - A vertical jump with a } \\
\text { well-balanced body } \\
\text { - The ball is protected by } \\
\text { one hand. } \\
\text { - Make sure that the } \\
\text { shooter's hand reaches } 45 \\
\text { to } 60 \text { degrees toward the } \\
\text { hoop. } \\
\text { - Maintain eye contact to the } \\
\text { target of the basketball } \\
\text { hoop }\end{array}$ \\
\hline Followthrough & $\begin{array}{l}\text { - Until the ball is in the } \\
\text { hoop, the arm remains in } \\
\text { the same position. } \\
\text { - Landing with both feet } \\
\text { balanced }\end{array}$ \\
\hline
\end{tabular}




\section{RESULTS}

Table 2. Results of expert judgement

\begin{tabular}{|c|c|c|c|c|c|c|c|c|c|c|c|c|c|}
\hline \multirow[t]{2}{*}{ Indicator } & \multirow[t]{2}{*}{ Item } & \multicolumn{10}{|c|}{ Expert Judgment } & \multirow[t]{2}{*}{$\mathrm{Ne}$} & \multirow[t]{2}{*}{ CVR } \\
\hline & & 1 & 2 & 3 & 4 & 5 & 6 & 7 & 8 & 9 & 10 & & \\
\hline \multirow[t]{3}{*}{ Preparatory } & 1 & 1 & 1 & 1 & 1 & 1 & 1 & 1 & 1 & 1 & 1 & 10 & 1 \\
\hline & 2 & 1 & 1 & 1 & 1 & 1 & 1 & 1 & 1 & 1 & 1 & 10 & 1 \\
\hline & 3 & 1 & 1 & 0 & 1 & 1 & 1 & 1 & 1 & 1 & 1 & 9 & 0,8 \\
\hline \multirow{4}{*}{$\begin{array}{l}\text { Implementat } \\
\text { ion }\end{array}$} & 4 & 1 & 1 & 1 & 1 & 1 & 1 & 1 & 1 & 1 & 1 & 10 & 1 \\
\hline & 5 & 1 & 1 & 1 & 1 & 1 & 0 & 1 & 1 & 1 & 1 & 10 & 1 \\
\hline & 6 & 1 & 1 & 1 & 1 & 1 & 1 & 1 & 1 & 1 & 1 & 10 & 1 \\
\hline & 7 & 1 & 1 & 1 & 0 & 1 & 1 & 1 & 1 & 1 & 1 & 9 & 0,8 \\
\hline \multirow{2}{*}{$\begin{array}{c}\text { Followthrou } \\
\text { gh }\end{array}$} & 8 & 1 & 1 & 1 & 0 & 1 & 1 & 1 & 1 & 1 & 1 & 9 & 0,8 \\
\hline & 9 & 1 & 1 & 1 & 0 & 1 & 1 & 1 & 1 & 1 & 1 & 9 & 0,8 \\
\hline
\end{tabular}

Table 3. Validity score

\begin{tabular}{|c|c|c|}
\hline Item & Validity Score & Remark \\
\hline Item 1 & 1.00 & Valid \\
\hline Item 2 & 1.00 & Valid \\
\hline Item 3 & 0.80 & Valid \\
\hline Item 4 & 1.00 & Valid \\
\hline Item 5 & 1.00 & Valid \\
\hline Item 6 & 1.00 & Valid \\
\hline Item 7 & 0.80 & Valid \\
\hline Item 8 & 0.80 & Valid \\
\hline Item 9 & 0.80 & Valid \\
\hline
\end{tabular}

Table 2 contains the results of the content validity ratio by expert. The CVR is an item statistic that can determine whether an item should be rejected or retained. Minimal value of CVR with ten experts is .80 [13][12]. So this performance-based instrument is acceptable in assessing the learning outcomes of layups.

\section{DISCUSSION}

The objective of the study was to estimate the value of content validity of the performance assessment instrument on lay up. Content validity is one of validity tests in instrument development process. In content validity test, a test item was categorized valid if it is properly developed based on the indicators, content, and learning objectives by the experts of the field [11][10].
Meanwhile, the analysis technique used in this study is Lawshe's content validity ratio.

The results show that the content validity using Lawshe's technique was ranging from 0.80 to 1.00 . the minimum number of the ratio was still higher than 0.50 indicating that even though there was an expert stating that it was not valid, it was actually valid over all [14].

There are many ways to measure the value of validity. A qualitative or quantitative technique can be used to establish the validity test [15]. Using an expert's judgment, the validity of the layup performance assessment instrument is determined. Finally, it has been demonstrated that the layup performance assessment instrument is a valid approach for assessing layup skills.

\section{CONCLUSION}

Based on the results and discussions, it is concluded that the lay up performance assessment instrument has high value validity contents, which increases the likelihood that it will be utilized for subsequent evaluation.

\section{REFERENCES}

[1] M. C. Drakos, B. Domb, C. Starkey, L. Callahan, and A. A. Allen, "Injury in the National Basketball Association: A 17-year overview," Sports Health, vol. 2, no. 4, pp. 284290, 2010, doi: 10.1177/1941738109357303.

[2] S. Chakraborty, P. Mondal Assistant Professor, C. Sankarshan Chakraborty, and P. Mondal, "Biomechanical factors contributing to effective layup shot in basketball: A review study," 
International, vol. 6, no. 3, pp. 86-89, 2019, [Online]. Available: www.kheljournal.com.

[3] H. Wissel, Steps to success Basketball. 2012.

[4] Y. H. K. Chua, R. K. K. Quek, and P. W. Kong, "Basketball lay-up-foot loading characteristics and the number of trials necessary to obtain stable plantar pressure variables," Sport. Biomech., vol. 16, no. 1, 2017, doi: 10.1080/14763141.2016.1174288.

[5] A. Mathankar and A. Saini, "Movement Pattern Analysis of Layup, Jump Shot and Free Throw in Basketball," Int. J. Physiother. Res., vol. 9, no. 4, pp. 3870-3875, 2021, doi: 10.16965/ijpr.2021.133.

[6] D. W. Prasetyo and Y. Sukarmin, "Developing Game Models for Basketball Basic Technique," J. Keolahragaan, vol. 5, no. 1, 2017.

[7] F. Erčulj and E. Štrumbelj, "Basketball shot types and shot success in different levels of competitive basketball," PLoS One, vol. 10, no. 6, 2015, doi: 10.1371/journal.pone.0128885.

[8] E. Panadero and A. Jonsson, "The use of scoring rubrics for formative assessment purposes revisited: A review," Educ. Res. Rev., vol. 9, pp. 129-144, 2013, doi: 10.1016/j.edurev.2013.01.002.

[9] R. P. Yudha, "Validity And Reliability Rubric Of Performance Assessment Geometry Study In Junior High School Using The Many Facet Rasch Model Approach," Eduma Math. Educ. Learn. Teach., vol. 9, no. 2, p. 26, 2020, doi: 10.24235/eduma.v9i2.7100.

[10] S. Sucipto, B. Tarigan, A. Ma'mun, and Y. Yudiana, "Content Validity of the Enjoyment Instrument in Physical Education Learning: A Field Study," vol. 11, no. Icsshpe 2018, pp. 389-391, 2019, doi: 10.2991/icsshpe18.2019.107.

[11] Y. S. L. N.K. Denzin, Handbook of Qualitative Research, Bahasa Ind. Yogyakarta: Pustaka Belajar, 2009.

[12] C. Ayre and A. J. Scally, "Critical values for Lawshe's content validity ratio: Revisiting the original methods of calculation," Meas. Eval. Couns. Dev., vol. 47, no. 1, pp. 79-86, 2014, doi: $10.1177 / 0748175613513808$.

[13] C. H. Lawshe, "A quantitative approach to content validity," in Personnel psychology, 1975, pp. 563-575.

[14] Tomoliyus, Sumaryanti, and H. M. Jatmika, "Development of Validity and Reliability of Net Game Performance-Based Assessment on Elementary Students' Achievement in Physical Education," Asian J. Assess. Teach. Learn., vol.
6, pp. 41-49, 2016.

[15] A. C. Lacy and D. N. Hastad, Measurement and evaluation in physical education and exercise science, 5th ed. San Fransisco: Pearson Education, Inc, 2007. 